\title{
Uluslararası İlişkilere Disiplinlerarası Yaklaşım: Tarih ve Teori Üzerine Bir Değerlendirme
}

Interdisiplinary Approaches in International Relations: An Evaluation on History and Theory

\section{Fulya ÖZKAN}

Dr. Öğr. Üyesi, Uluslararası İlişkiler Bölümü, Akdeniz Üniversitesi

\section{Bu makaleye atıf için}

Özkan, Fulya, "Uluslararası İlişkilere Disiplinlerarası Yaklaşım: Tarih ve Teori Üzerine Bir Değerlendirme", Uluslararası İlişkiler, Cilt 16, Say1 61, 2019, s. 5-22, DOI: $\underline{10.33458 / \text { uidergisi.541513 }}$

Makaleye Erişim İçin: https://dx.doi.org/10.33458/uidergisi.541513

Makale Gönderim: 07 Mart 2018

Basım Tarihi: 01 Mart 2019

\section{Uluslararası İlişkiler Konseyi Derneği | Uluslararası İlişkiler} E-Posta: bilgi@uidergisi.com.tr

Bu makalenin tüm hakları Uluslararası İlişkiler Konseyi Derneğine aittir. Önceden yazılı izin almadan hiçbir iletişim, kopyalama ya da yayın sistemi kullanılarak yeniden yayımlanamaz, çoğaltılamaz, dağıtılamaz, satılamaz veya herhangi bir sekilde kamunun ücretli/ücretsiz kullanımına sunulamaz. Akademik amaçlı alıntılar bu kuralın dışındadır. Yazıda belirtilen fikirler yalnızca yazarına/yazarlarına 


\title{
Uluslararası İlişkilere Disiplinlerarası Yaklaşım: Tarih ve Teori Üzerine Bir Değerlendirme
}

\author{
Fulya ÖZKAN \\ Dr. Öğr. Üyesi, Uluslararası İlişkiler Bölümü, İIBF, Akdeniz Üniversitesi, Antalya. \\ E-posta:fulyaozkan@akdeniz.edu.tr
}

\section{ÖZET}

$\mathrm{Bu}$ makalenin amacı uluslararası ilişkiler ve tarih disiplinleri arasındaki etkileşime değinerek sosyal bilimlerdeki disiplinlerarası yaklaşımın önemini vurgulamaktır. Makalenin ilk kısmında uluslararası ilişkilere içkin büyük tartışmalarda tarihin oynadığı role değinilecek, ardından pozitivist uluslararası ilişkiler kuramlarının ortaya çıktığı tarihsel bağlam incelenecektir. Tarih ve uluslararası ilişkiler disiplinleri arasındaki etkileşim bu şekilde önce ontolojik ardından epistemolojik açıdan ele alındıktan sonra tarihsel yöntemi kullanan uluslararası ilişkiler teorilerinin alana yaptığı metodolojik katkı incelenecektir. Bu analiz neticesinde, tarihsel sosyoloji gibi farklı mekânsal kurguları göz önünde bulunduran çalışmalar sayesinde uluslararası ilişkilerin başat teorilerine içkin Avrupa-merkezci anlayıştan uzaklaşılabileceği sonucuna varılacaktır.

Anahtar Kelimeler: Uluslararası İlişkiler, Tarih, Disiplinlerarasılık, Pozitivizm, Tarihsel Sosyoloji

\section{Interdisiplinary Approaches in International Relations: An Evaluation on History and Theory}

\begin{abstract}
This article emphasizes the importance of interdisiplinarity in the social sciences by analyzing the relationship between international relations and history. The first section examines the influence of history in the emergence of the great debates of international relations. The second section analyzes the historical context in which positivist international relations theories emerged. After these ontological and epistemological perspectives, the article concludes with an overview of how post-positivist theories have contributed to the field methodologically by making use of historical approaches. This multi-level analysis will show the long history of the interaction between the two disciplines, and further point out that historical international relations may help overcome Eurocentricism, which is an intrinsic characteristics of the main international relations theories.
\end{abstract}

Keywords: International Relations, History, Interdisiplinarity, Positivism, Historical Sociology 


\section{Giriş}

Ramazan Gözen editörlügünü yaptı̆̆ı Uluslararası İlişkiler Teorileri kitabında teorinin, uluslararası ilişkiler disiplini için, ama özellikle de Türkiye'deki uluslararası ilişkiler açısından neden önemli olduğuna değinirken alanın gündelik yaşama yansıma biçimlerinden yakınır. Burak Bilgehan Özpek'le birlikte dile getirdikleri temel sorunlar arasında, uluslararası ilişkiler öğrencilerinin "bir falcı gibi kehanette” bulunmasının istenmesi yer almaktadır. ${ }^{1}$ Yazarların yakındıkları bir diğer husus televizyondaki tartışma programlarında konusu edilen uluslararası ilişkilerin, çok büyük oranda komplo teorileri ve spekülasyondan öteye geçememesidir. Küresel siyasetteki güncel gelişmelere odaklanan uluslararası ilişkilerin amacı, yaşanan gündelik sorunlara çözüm üretmek ve öngörüde bulunmakla sinırlıdır. ${ }^{2}$

Yazarların uluslararası ilişkiler için yaptığı tespitin bir benzerinin, Türkiye'deki bir başka alan için de geçerli olduğu söylenebilir. Uluslararası ilişkiler nasıl devletler arası güncel olayların takibi şeklinde bir gazetecilik faaliyetine indirgeniyorsa tarih de geçmiş olayların kronolojik anlatımına, hatta ezberine indirgenmiştir. ${ }^{3}$ Uluslararası ilişkiler güncel küresel olaylara odaklanırken tarihçinin görevi geçmişin "güncel” olaylarını aktarmaktır. Yani uluslararası ilişkiler günümüz, tarih ise geçmiş anlatısına dayalıyken her ikisinin de ortak noktası olay odaklı olmasıdır. Gerek geçmişte gerekse günümüzde yaşananlar aktarılırken olayların ortaya çıkmasına neden olan uzun erimli yapısal dönüşümler göz ardı edilir.

Bununla bağlantılı olarak, her iki alanın Türkiye'deki ortak sorunu, ne uluslararası ilişkiler ne de tarih disiplininde teorik altyapının yeterli olmayışıdır. ${ }^{4}$ Oysa teoriye verilecek önem, her iki disiplinin benzer yaklaşım ve yönelimlere sahip olduğunu, sadece birinin geçmişi, diğerinin günümüzü incelediğini gösterebilir. Diğer bir deyişle teori odaklı bakış açısı disiplinlerarası yaklaşımın önünü açabilir. Teori, meselelere olay odaklı bakmak yerine farklı analiz yöntemlerini kullanmamızın önünü açar. Bu makalede, olay odaklı bir biçimde ele alındıklarında çok farklı alanlar gibi gözükmesine rağmen tarih ve uluslararası ilişkilerin teorik ve yöntemsel açıdan birbirlerini besledikleri gösterilmeye çalışılacaktır.

Sosyal bilimleri birbirinden ayrıştırarak disiplinlerarası yaklaşımın ortaya çıkmasının gecikmesinde, pozitivizmin toplumsal hayatı gözlemlenebilir parçalara ayırması yaklaşımı etkili olmuştur. ${ }^{5}$ Pozitivizm sadece gözlemlenenin bilimsel olabileceğini kabul etmiş, incelediği nesne ya da olgunun geçmişiyle ilgilenmemiştir. Şimdiki zamanın tarihsel olarak nasıl kurgulandığı konusu ilgi alanı dışında kalmıştır. Dolayısıyla pozitivizm, düzenlilikler peşinde koşmuş, bu sayede hem genelleme yapmak hem de geleceğe dair kestirimde bulunmak mümkün olmuştur. Bu ise zaman ve mekân dışı analizler yapılmasını gerektirmiştir.

$\mathrm{Bu}$ değerlendirmeler ışığında makalenin amacı, kuramsal açıdan yaklaşıldığında tarih ve uluslararası ilişkiler arasında disiplinlerarası bir ortaklık kurulabileceğini vurgulamaktır. Aşağıda da ele alınacağı üzere, uluslararası ilişkiler disiplini ilk ortaya çıktığında sömürgeci devletler ile sömürge

1 Ramazan Gözen ve Burak Bilgehan Özpek, “Sonuç”, Ramazan Gözen (der.), Uluslararası İlişkiler Teorileri, İstanbul, İletişim Yayınları, 2014, s.565.

2 Aydınlı et al. uluslararası ilişkilerin herkesin hakkında fikir sahibi olduğu bir alan haline gelmesinden yakınır. Bkz. Ersel Aydınlı et al., Yöntem, Kuram, Komplo, İstanbul, Küre Yayınları, 2015.

3 Erol Kurubaş, “Türkiye’de Uluslararası İlişkiler Yazınında Tarihsel Olguculukla Disiplinlerarasıcıllı̆ın Analitik Yaklaşıma Etkisi ve Türkiye Uygulaması”, Uluslararası İlişkiler, Cilt 5, No.17, 2008, s.131, 138.

4 Ibid., s.130.

5 Ibid., s. 140. 
toplumlar arasındaki ilişkiye dair bir tartışma yürütmüş; birbirinden farklı mekânsal unsurlar arasındaki etkileşimi incelemiştir. Ancak daha sonra alana hâkim olan realizm benzeri teorik yaklaşımlar, kullandıkları kavramların tarihselliğini gözardı ettikleri ölçüde bu tür mekansal farklılıkları bir kenara bırakarak egemen ulus-devlet kavramını evrensel bir norm olarak ele almış ve bu da uluslararası ilişkilerin alanının Avrupa-merkezci konu ve bakış açılarıyla kısıtlamasına neden olmuştur.

Aslında bu tespitin, uluslararası ilişkilerin kurumsallaşmaya başladığı yıllardaki ilgi alanı olan sömürgecilik yazınının geneline hâkim olduğu söylenebilir. Zira ilk emperyalizm kuramları inceledikleri konuyu sömürgeci devletler arasındaki ilişkiye indirgemiş; sanayileşmemiş ülkeler açısından sömürgeciliği onların kapitalistleşmesini hızlandıracak bir unsur olarak ele almıştır. Ancak tarihsel sosyolojiden etkilenen Bağımlılık Okulu ve Dünya Sistemleri Teorisi gibi sonraki dönemin emparyalizm kuramları, çalışma alanlarını Batı merkezli olmaktan çıkartmış; konuyu sadece sömürgeci devletler değil, merkez ve çevre ülkeler arasındaki ilişki bağlamında ele almıştır. ${ }^{6}$

$\mathrm{Bu}$ nedenle tarihsel analizlerden uzak durarak Avrupa'da yaşanan toplumsal dönüşümler neticesinde ortaya çıkan modern devlet gibi kavramları evrensel modellermiş gibi ele alan çalışmalar, ne sadece uluslararası ilişkilere içkindir ne de sadece onun başat teorilerinden biri olan realizmin sorunudur. Meselenin özünde aşağıda da ele alınacağı üzere pozitivist bilgi felsefesinin ve onunla bağlantılı olarak Aydınlanmacı düşüncenin içselleştirdiği doğrusal çizgide ilerleyen zaman anlayışı yatar. $\mathrm{Bu}$ tür bir zaman mevhumu, ironik bir şekilde tarihin önemini diğer sosyal bilim dalları açısından azaltmıştır. Çünkü doğrusal zaman algısı, gelişmiş sanayi toplumlarının izlediği seyri temel alarak tarihi adeta dondurmuş, dünyanın geri kalan coğrafyalarında yer alan devletlerin de benzer modeller izleyeceğini öngörerek Avrupa tarihi bağlamında şekillenen kavramların tüm dünya geneline uyarlanmasına neden olmuştur. Bu nedenle tarihsel analizden uzaklaşıldıkça sosyal bilimcilerin mekânsal ufku da daralmıştır.

Bu durumu uluslararası ilişkiler disiplini içerisinde de gözlemlemek mümkündür. Uluslararası ilişkiler çalışanları ancak tarihsel yöntemi kullanmaya başladıkları ölçüde çok boyutlu bir mekânsal düzleme erişebilirler. Diğer bir deyişle, pozitivizmin farklı sosyal bilim dalları kompartmantelize edildikçe etkileşim içerisinde olan farklı mekânlar birbirinden kopartılmıştır. Uluslararası ilişkiler disiplininin yeniden tarihsel analizler yapmaya başlamasıyla, özellikle de tarihsel sosyolojinin ve 'eşitsiz birleşik gelişim’ kavramının etkisiyle aynı zaman dilimini paylaşan farklı mekânlar arasındaki bağlantı ve çok boyutlu etkileşimler yeniden hatırlanmış ve uluslararası ilişkiler disiplini gerçek anlamda bir 'uluslararası' nitelik kazanmaya başlamıştır.

$\mathrm{Bu}$ çerçevede ilerleyen bölümlerde uluslararası ilişkiler ve tarih disiplinleri arasındaki ilişki üç ayrı eksen çerçevesinde ele alınacaktır. Öncelikle ontolojik olarak, uluslararası ilişkilerin büyük tartışmalarına tarihin nasıl katkıda bulunduğu incelendikten sonra en son tartışma konularından birisi olan pozitivizm ve post-pozitivizm arasındaki ayrışmada tarihin pragmatik ${ }^{7}$ bir bakış açısı geliştirmeyi sağlayabileceğine dair görüşlere yer verilecektir. İkinci olarak epistemolojik eksende, tarihin uluslararası ilişkiler kuramlarının ortaya çıkmasında oynadığı role değinildikten sonra tarihsel bakış açısının uluslararası ilişkiler kuramlarının çeşitliliğinden faydalanmayı sağlayacak çoğulcu bir analiz

6 Engin Sune, “Emperyalizm Kuramları ve Uluslararası İlişkiler”, Faruk Yalvaç (der.), Tarihsel Materyalizm ve Uluslararası İlişkiler, Ankara, İmge Kitapevi, 2017, s.100.

7 Burada pragmatizmle, bilgi felsefesinde, doğru bilgiyi yarattığı sonuçlar açısından değerlendiren yaklaşım ifade edilmektedir. 
sunabileceği öne sürülecektir. Son olarak, özellikle tarihsel sosyoloji bağlamında, metodolojik olarak tarihsel yöntemin uluslararası ilişkilere sunduğu katkı incelenecek ve tarihin uluslararası ilişkilere içkin bir diğer tartışma konusu olan analiz düzeyleri ayrışmasına nasıl netlik kazandırabileceği konusu sorgulanacaktır.

\section{Uluslararası İlişkilerin Büyük Tartışmaları: Ontolojik Analiz}

Uluslararası ilişkilere içkin büyük tartışmalara baktığımızda tarih ve uluslararası ilişkiler arasındaki etkileşimin oynadığı rolü açıkça görürüz. Örneğin davranışsalcılık ve gelenekselcilik arasında geçen ikinci tartışmada, uluslararası ilişkilerin izlemesi gereken yöntem sorgulanmıştır. Davranışsalcılık, birinci tartışmada farklı taraflarda yer alan idealizm ve realizmi aynı potada eriterek her ikisini de gelenekselcilik çatışı altında birleştirmiş̧ir.. ${ }^{8}$ Gelenekselcilikten kasıt, davranışsalcılar tarafından bilimsel bulunmayan tarihsel yöntemin kullanılmasıdır. Uluslararası ilişkiler kısmen tarihin içerisinden çıkan bir disiplin olduğu için ilk dönemlerde tarihsel anlatı alana hâkim olsa $\mathrm{da}^{9}$ zamanla tam da bu yüzden, yani "belki de uluslararası ilişkiler tarihin çocuğu olduğu için geliştikçe kendisini ondan uzaklaştırmaya çalışmış, yöntemsel ve kuramsal yeniliklere girişerek evrensel bilgi arayışı içerisine girmiştir." ${ }^{10}$ Dolayısıyla davranışsalcılıkla gelenekselcilik arasındaki gerilim, epistemolojik olmaktan çok metodolojik bir tartışma olarak nitelendirilmiştir. Davranışsalcılar disipline nicel yöntemlerle istatistiksel açıdan yaklaşmış ve genellemeler yaparak uluslararası ilişkilerin yasalarına ulaşmaya çalışmıştır. Gelenekselcilerse yorumlamaya, olumsallığa, tarihselliğe ve uluslararası ilişkilerin karmaşıklığına dikkati çekmiştir. Kullandıkları temel araçlar tarihsel, diplomatik ve hukuki analizler olmuştur. Bu yüzden davranışsalcılar, genellemeler yapmak yerine tikel olaylarla ilgilenen gelenekselcileri bilimsel olmamakla suçlamıştır.

Buradaki sorun, pozitivist bilim felsefesinin tarihsellikle bilimsellik arasında varolduğunu düşündüğü zıtlıktır. Tarihin biricik ve tikel olaylarla ilgilendiği varsayıldığı için genelleme yapmasının zor olması, onun bilimselliğine gölge düşürmüştür. Bu rekabetten kısa vadede gelenekselcilere karşı davranışsalcıların pozitivizmi galip çıkmıştır. Nitekim ikinci tartışmayı takip eden üçüncü paradigmalar arası tartışmada yeniden epistemolojik argümanlara dönülmüş, tartışmanın tarafı olan realizm, çoğulculuk (plüralizm) ve Marksizmin üçü de metodolojik olarak pozitivizme sadık kalmayı tercih etmiştir. Hatta tam da bu yüzden üçüncü tartışma bazı uluslararası ilişkiler çalışanları tarafından yapay olarak nitelendirilmiştir. ${ }^{11}$ Ancak bu metodolojik bütünlüğün yanı sıra paradigmalar arası tartışma epistemolojik olarak realizm, yapısalcılık ve çoğulculuk arasındaki ayrımı korumuş, hatta bu durum analiz düzeyleri arasındaki yapay tartışma gibi "gerçeğin farklı katmanları arasındaki ilişkiyi birbirinden kopartarak" devlet dışı aktörlere odaklanan çoğulculuk ve devletler arasındaki

8 Mustafa Aydın, “Uluslararası İlişkilerde Yaklaşım, Teori, Analiz”, Ankara Üniversitesi Siyasal Bilgiler Fakültesi Dergisi, Cilt 51, No.1, 1996, s.94-95.

9 Halvard Leira ve Benjamin de Carvalho, "Historical International Relations”, Halvard Leira ve Benjamin de Carvalho (der.), Historical International Relations, Sage Publications, 2015, s.xix.

10 Thomas Smith, History and International Relations, Londra \& New York, Routledge, 1999, s.1.

11 Steve Smith, "Uluslararası İlişkiler Teorisinde Çeşitlilik”, Tim Dunne et al. (der.), Uluslararası İlişkiler Teorileri, Sakarya Üniversitesi Yayınları, 2016, s.5; Milja Kurki ve Colin Wight, "Uluslararası İlişkiler ve Sosyal Bilimler”, Dunne et al., Uluslararası İlişkiler Teorileri, s.20; Faruk Yalvaç, “Uluslararası İlişkilerde Teori Kavramı ve Temel Teorik Tartışmalar”, Ramazan Gözen (der.), Uluslararası İlişkiler Teorileri, İstanbul, İletişim Yayınları, 2014, s.46; Tayyar Arı, "Uluslararası İlişkilerde Büyük Tartışmalar ve Postmodern Teoriler”, Tayyar Arı (der.), Postmodern Uluslararası İlişkiler Teorileri, Bursa, Dora Yayınları, 2014, s.6. 
eşitsiz ilişkilere odaklanan yapısalcılığın karşısında, realizmin uluslararası ilişkilerde devletin rolünü inceleyen başat teori olma rolünü güçlendirmiştir. ${ }^{12}$

Sosyal bilimciler yaşanan tartışmalar neticesinde zamanla, genelde sosyal bilimlerde ve özelde uluslararası ilişkilerde, evrensel yasalar bulmak ve sosyal düzeni sağlamak dışında da hedefler gütmeye başlamıştır. Bunun uluslararası ilişkilere yansıması, pozitivistlerle postpozitivistler arasında yaşanan dördüncü tartışmadır. Postpozitivistler, epistemolojik olarak birbiriyle çelişiyor gibi gözüken idealizm, realizm, davranışsalcılık, yapısalcılık ve Marksizm gibi çok farklı teorilerin pozitivizmin ortak penceresinde birleştiğini iddia etmiştir. ${ }^{13}$ Bu teoriler tarafından doğal kabul edilen varsayımları sorgulamış; bu bağlamda ulusal çıkar gibi unsurları dikkate alan ve nedenselliğe önem veren açılayıcı teoriler karşısında kimlik, norm ve değerler gibi faktörlere önem veren ve açıklamaya değil, anlamaya yönelik yorumsamacı teoriler önem kazanmaya başlamıştır. Dolayısıyla tartışma ekseni yeniden metodolojiye kaymıştır.

\section{Pragmatizm ve Uluslararası Iilişkilerin Siyasi Niteliği}

Tam da bu noktada, yani uluslararası ilişkilerde pozitivist ve postpozitivist yaklaşımlar arasındaki tartışma düşünüldüğünde Puchala, tarih ve uluslararası ilişkiler arasındaki ilişkiye pragmatik açıdan yaklaşılabileceğini belirtmektedir. Uluslararası ilişkiler çalışanları genellemelere dayalı oluşturdukları teorileri test etmek, doğrulamak veya yanlışlamak için tarihe başvurmuştur. Ancak en ılımlı şekliyle Kuhn'la başlayıp Foucault'nun bilgi ve iktidar arasında kurduğu ilişkiye dayalı eleştiri ağı göz önünde bulundurulduğunda gerçeklik, bilim insanlarının bildiklerinden çok bildiklerine inandıkları şeydir ve bu yüzden 'bildiğimizle inandığımızı ayrıştırmak zordur'. O halde 'başvurulacak nesnel bir gerçeklik yoksa' tarih ve uluslararası ilişkiler arasındaki etkileşimi, yani teorileri test etmek için geçmişten seçilen örnekleri siyaseten 'işe yarayıp yaramadıkları' noktasında değerlendirmek gerekir. Aşağıda da ele alınacağı üzere önce idealizmin, 20. yy’ın ikinci yarısından itibaren realizmin rağbet gören kuramlar olarak öne çıkması bu nedenledir. ${ }^{14}$ Hatta bu paradigmalarla siyasi düşünce tarihinin önde gelen figürleri arasında geçmişe dönük bağlantılar kurularak disiplin içerisinde varolan tartışmalar meşrulaştırılmaya çalışılmıştır. ${ }^{15}$

Isacoff da tarih ve uluslararası ilişkiler arasındaki ilişkiye, pragmatist açıdan yaklaşmıştır. Isacoff, gelenesekselcilerin nesnel pozitivizt anlayışıyla postmodernlerin öznel görececiliği arasındaki zıtlı̆̆a dikkati çekerek, bu ikiliği aşmanın yolu olarak pragmatizmi savunmuştur. Tarihin günümüzün sorunlarına ve ihtiyaçlarına göre yorumlanarak şekil bulması, pragmatik bakış açısının işe yarar bilgiye odaklanarak postmodern görececilikle pozitivist evrenselcilik arasında ortak bir yol bulmasını kolaylaştıracaktır. ${ }^{16}$

12 Yalvaç, “Uluslararası İlişkilerde Teori Kavramı ve Temel Teorik Tartışmalar”, s.48; Faruk Yalvaç, "Uluslararası İlişkiler Teorisindeki Temel Tartışmalar ve Eleştirel Gerçekçilik”, Tayyar Arı (der.), Uluslararası İlişkilerde Postmodern Analizler, Bursa, MKM Yayıncilık, 2012, s.23-24.

13 Erdem Özlük, “Uluslararası İlişkiler Disiplininin Doğuşu, Kimliği ve Sorunları”, Şaban Kardaş ve Ali Balcı (der.), Uluslararası İlişkilere Giriş, İstanbul, Küre Yayınları, 2014, s.110.

14 Donald Puchala, "Pragmatics of International History”, Mershon International Studies Review, Cilt 39, No.1, 1995, s.3, 13, 16.

15 Brian Schmidt, The Political Discourse of Anarchy, State University of New York Press, 1998, s.32.

16 Jonathan Isacoff, "On the Historical Imagination of International Relations”, Millennium, Cilt 31, No.3, 2002, s.607$608,616-617,620$. 
McCourt da 'uluslararası ilişkilerin tarihe ilgi duymaya başlamasını, tüm sosyal bilimlerde yaşanan pozitivizmden uzaklaşmanın parçası' olarak görmüştür. Her ne kadar ‘Tarih nedir?’ sorusunun tek bir yanıtı olmadığını kabul etse de McCourt'a göre tarih "günümüze dair siyasi amaç ve projeler tarafından şekillenir." Bu çerçevede sadece hatırlanmaya değer görülen geçmiş olaylar anımsanır. Tarih sadece "onu yazanların eylemlerinin bir sonucudur." Bu yüzden uluslararası ilişkiler çalışanlarının "sadece dünya politikasının değil, onu incelerken kullandıkları kavram ve yöntemlerin de tarihsel olarak belirlendiğini" kabul etmesi gerekir. Pozitivist olmayan toplum bilim, "zaman ve mekândan bağımsız nesnel bilgiye olan inancı sarstığı için şimdiki zamanın siyasi bağlamıyla alakalıdır.” Dolayısıyla pozitivist olmayan bilgi 'doğası gereği pratiktir' ve uluslararası ilişkilerin yüzünü tarihe dönmesi, aynı zamanda pratik bilgiye dönüştür. Diğer bir deyişle, uluslararası ilişkiler ve tarih arasındaki etkileşim, aslında "akademik bilgi üretimiyle siyaset dünyası arasındaki ilişkiyle" alakalıdır. ${ }^{17}$

Bu bağlamda düşünüldüğünde tarihin sadece geçmiş değil, günümüz ve gelecekle de alakalı bir yanı bulunmasından ötürü uluslararası ilişkilere içkin tarihsel bakış açısı, disiplinin politik karakterine dikkati çekmiştir. Realizmin değişime ve tarihe yeteri kadar önem vermemesinden ötürü şimdicilik ve statükoculukla eleştirilmesine örnekler veren Davenport, "tarihsel süreç ve değişimin reddinin, insanların kendi varoluşsal koşullarını değiştirme ve şekillendirme yetisinin de reddi olarak algılanmasına, dolayısıyla uluslararası ilişkilerdeki tarih sorunsalının geçmişin akademik olarak çalışılmasından öte, özgürlük ve siyasal özne kavramları hakkında bizi düşünmeye sevk ettiğine” dikkat çekmiştir. Tüm bunlar sonucunda Davenport, uluslararası ilişkiler ve tarih arasındaki ilişkinin, sadece uluslararası ilişkiler kuramlarını tarihsel veriler çerçevesinde test etmeye indirgenemeyeceğine değinerek, bunun tarihi uluslararası ilişkiler disiplinine dışsallaştırdığını ve tarihe teorik tartışmalar açısından yaklaşan bir bakış açısının yokluğunda pragmatik değil, tam aksine 'dogmatik' sonuçlara neden olabileceğini belirtmiştir. ${ }^{18}$

Oysaki tam aksine uluslararası ilişkilerin değişim kavramına odaklanarak tarihselleştirilmesi, bize bugün ve geçmişte var olan düzenden farklı bir dünyanın kurulabileceğini hatırlatır. Nitekim önce Horkheimer'in, ardından Cox'un geliştirdiği geleneksel/problem çözücü ve eleştirel teori ayrımında, tarihsel analiz rol oynamıştır. Geleneksel teorilerin bugüne ait sorunları çözme odaklı bakış açısı, var olan koşulları meşrulaştırmaya ve sürekli kılmaya hizmet ederken tarihsel yaklaşımı içerisinde barındıran eleştirel teori, geçmişten günümüze değişen süreçleri analiz ederek değişim olgusu sayesinde eşitlikçi ve özgürlükçü bir dünyanın kurulabilme ihtimaline işaret eder. ${ }^{19}$ Ancak tarihin uluslararası ilişkiler disiplinine etkisi, sadece büyük tartışmalar eksenli olmamıştır. Büyük tartışmaların tarafı olan uluslararası ilişkiler kuramlarıyla tarih arasında yakın bir ilişki vardır. Tarih bize bu kuramların belli toplumsal bağlamlarda ortaya çıktığını, revize edildiğini ve yeniden önem kazandığını gösterir. Aşağıdaki bölümde bu husus ele alınacaktır.

17 David McCourt, "What's at Stake in the Historical Turn?", Millenium, Cilt 41, No.1, 2012, s.25-26, $28,33$.

18 Andrew Davenport, “The International and the Limits of History”, Review of International Studies, No.42, 2016, s.253254, 264.

19 Max Horkheimer, "Traditional and Critical Theory", Critical Theory, New York, Continuum, 1989. Robert Cox, "Social Forces, States and World Orders", Millennium, Cilt 10, No.2, 1981. 


\section{Uluslararası İlişkiler Kuramları ve Tarih: Epistemolojik Analiz}

Tarihe bakmak bize belli dönemlerde ön plana çıkan uluslararası ilişkiler teorilerinin, yani uluslararası ilişkiler disiplininin kendisinin de bir tarihi olduğunu gösterir. ${ }^{20}$ Bu bağlamda tarih, uluslararası ilişkiler teorilerinin hangi dış politika pratiklerini meşrulaştırdığını ve tarafsız teori olamayacağını ortaya koymak için gereklidir. Kuramsal bilgi, zaman ve mekândan bağımsız değildir. Bunu en iyi, her teorinin aslında bir zaman ve mekânı olduğunu, çünkü birileri için bir amaç doğrultusunda yazıldığını belirten Cox ifade etmiştir. ${ }^{21}$ Her teori aslında tarihseldir, toplumsaldır ve siyasaldır. Nitekim Smith de "tutarlı 'yasalar' ve uluslararası davranış modelleri bulmak için yüzünü teoriye dönenlerin, teorilerin çağdaş siyasi sorun ve yapılara paralellik taşıdığını gördüğünde hayal kırıklığına uğrayacağını”22 belirtmiştir.

Benzer şekilde tarihçi de güncel sorunlar çerçevesinde geçmişle ilgilenir. Örneğin geçmişte yaşanan her olay hatırlanmaz. Aksine farklı tarihsel olay ve yaklaşımlar, güncel politika çerçevesinde önem kazanır. ${ }^{23}$ Geçmiş, nesnel bir resim sunmaz; aksine geçmişten neyi nasıl hatırladığımızı belirleyen, güncel kaygılarımızdır. Tarih, "tarihçiyle gerçekler arasında durmaksızın devam eden bir etkileşim süreci, geçmişle günümüz arasında süren sonsuz bir diyalogdur." ${ }^{24}$ Croce'ye göreyse "her tarihsel yargının altında yatan pratik gereklilikler bütün tarihi 'güncel tarih' kılarken”25, Oakeshott da tarihi, "tarihçinin deneyimi” şeklinde tanımlar: “Tarih, tarihçi dışında kimse tarafından 'yapılmaz', tarihi yazmak onu yapmanın tek yoludur."26

Benzer şekilde uluslararası ilişkilerin tarihi de kendi döneminin güncel kaygılarını yansıtır biçimde şekillenmiştir. Amerikan Siyaset Bilimi Derneği’nin amaçlarından birisi siyasetin bilimsel olarak çalışılması olduğu için 19. yy'ın sonunda sömürgeciliğin incelenmesi en hassas konulardan birisi haline gelmiş ve böylelikle uluslararası ilişkiler tarihinin şekillemesindeki ilk sacayaklarından birisini sömürgecilik teşkil etmiştir. Bu dönemde siyaset bilimciler yönetim yapısı üzerine çalışırken siyaset biliminin uluslararası niteliğiyle ilgilenenler sömürgeci yönetimleri incelemiştir. Özellikle ABD gibi sömürgecilik yarışına geç katılan bir ülkede, bu durum daha da elzem bir hal almıştır. Bu nedenle Schmidt, uluslararası ilişkiler disiplininin tarihini Birinci Dünya Savaşı gibi gerçek olaylara dayalı dışsal bir bağlamla başlatmak yerine önceki dönemde siyaset bilimcilerin kendi aralarında yaptıkları tartışmalara dikkati çekerek alanın söylemsel tarihinin yazılabileceğine belirtmiştir. ${ }^{27}$

Dolayısıyla uluslararası ilişkiler disiplininin doğuşu, aslında sonrasında alana hâkim olacak olan idealizm ve realizm gibi teorilerin iddia ettiğinin aksine egemen devletlerin oluşturdukları dünya düzeninden ziyade gelişmiş devletler ile sömürge toplulukları arasındaki ilişkiye dayalı olmuştur.

20 Smith, "Uluslararası İlişkiler Teorisinde Çeşitlilik", s.9.

21 Cox, "Social Forces, States and World Orders", s.128.

22 Smith, History and International Relations, s.28.

23 Walter Benjamin, “Theses on the Philosophy of History”, Illuminations, New York, Schocken Books, 1969.

24 E. H. Carr, What Is History?, London, Penguin Books, 1990, s.30.

25 Benedetto Croce, History as the Story of Liberty, London, Clements Newling and Co., 1949, s.19.

26 Micheal Oakeshott, Experience and its Modes, Cambridge University Press, 1966, s.99.

27 Brian Schmidt, "Political Science and the American Empire", International Politics, No.45, 2008, s.676, 678-679, 682; Brian Schmidt, "Lessons from the Past", International Studies Quarterly, Cilt 42, No.3, 1998, s.439. 19. yy sonunda tarihyazımı da sömürgeciliği dikkate alarak şekil bulmuştur. Sömürgeci politikalara maruz kalan Hint ve Çin uygarlıkları, her ne kadar Oryantalist bakış açısına sahip olsa da Ranke tarafından yazmak istediği dünya tarihinin edilgen diyebileceğimiz parçaları olarak görülmüştür. İki savaş arası dönemde ise uluslararası ilişkilerin Batılı devletler merkezli bir hal almasına paralel şekilde tarihyazımı da sadece ulusların tarihiyle ilgilenmeye başlamıştır. George Iggers, Yirminci Yüzyılda Tarihyazımı, İstanbul, Tarih Vakfı Yurt Yayınları, 2016, s.35. 
Diğer bir deyişle, tarihten yararlanarak farklı mekânsal analizler ortaya koyan son dönem teorileri, aslında uluslararası ilişkilerin ilk ortaya çıkış dönemiyle benzer ilgi alanlarına sahiptir. Kısacası alanın yapıtaşları olarak nitelendirdiğimiz idealizm ve realizme, belki de 'tali' teoriler olarak bakmak gerekir. Nitekim Düzgün'ün de dediği gibi tarihsel sosyolojinin etkisiyle uluslararası ilişkiler çalışanları moderniteyle sömürgeciliğin birbirini kurduğunu keşfetmiş ve bu bağlamda disipline hâkim Batı́nın üstünlüğü algısını sorgulamaya başlamıştır. ${ }^{28}$

Hatta bu noktada Schmidt, uluslararası ilişkiler tarihini idealist, realist, davranışsalcı gibi safhalara ayıran anlayışa da toptan karşı çıkmıştır. Ona göre bu ayrımlarla bir uluslararası ilişkiler geleneği yaratılmaya çalışılmaktadır. Ancak Hobsbawm'ın ünlü 'geleneğin icadı' kavramına gönderme yapan Schmidt, bu çabanın da tüm gelenekler gibi aslında eski değil yeni girişimler olduğunun altını çizmiştir. Bu nedenle, örneğin realist uluslararası ilişkiler tarihini Machiavelli, hatta Thucydides gibi figürlere dayanarak geriye dönük şekilde okumak mantıklı değildir. Bunun yerine disiplinin geçmişini anlamak için asıl yapılması gereken, bu alanda çalışan akademisyenlerin kendi aralarında gerçekleştirdiği diyalog ve tartı̧̧malara odaklanmaktır. Bu şekilde uluslararası ilişkilerin söylemsel tarihini yazmak, disiplinle dünya siyasetinde vuku bulan gerçek olaylar arasında birebir örtüşen bir ilişki kurmaktan daha faydalı olabilir. Çünkü uluslararası politikada yaşanan bir gelişmeyle bu alanda çalışan kişilerin buna verdiği tepki arasında zamansal bir örtüşme yoktur. Ayrıca uluslararası sistemde yaşanan her dönüşüme düşünsel anlamda cevap verilmediği gibi verilen tepkiler de birbirinden farklı olabilir. Dolayısıyla dışsal olaylarla alanın kendi içerisinde yürüttüğü söylemsel tartışma arasında nedensel bir ilişki kurmak yerine dışsal bağlamın akademisyenler tarafından nasıl algılandığına odaklanmak gerekir. ${ }^{29}$

Nitekim uluslararası ilişkilerin ilk teorilerinden idealizmin ortaya çıkışına bu perspektiften bakıldığında 1. Dünya Savaşı sonrasında savaşın bir daha yaşanmaması hedefinin güdülmesi etkin rol oynamıştır. ABD Başkanı Wilson açık diplomasi, silahsızlanma, self-determinasyon ve uluslararası güvenlik gibi ilkeler çerçevesinde barışın sağlanabileceğini düşünmüştür. İdealizme yöneltilen eleştiri ABD’nin çıkarına olan politikaları tüm dünyanın iyiliğine hizmet edecek evrensel kriterlermiş gibi gösterdiğidir. ABD sömürgecilik yarışına geç katıldığı için ulusların kendi kaderini tayin hakkı gibi ilkeler, ABD'nin çıkarına hizmet etmiştir. Örneğin Hobsbawm kendi kaderini tayin hakkını idealizme bağlamak yerine, kavramın aynı yıllarda rakip güç olarak doğmakta olan Sovyetler Birliği’nin ve genel olarak Marksizm'in enternasyonalizmine tepkisel bir alternatif olarak öne sürüldüğünü iddia etmiştir. ${ }^{30}$ Tüm bunlar göz önünde bulundurulduğunda Wilson idealizminin aslında 'Amerikan realizmi' olduğu söylenebilir.

Nitekim idealizmin 1930'larda yaşanan siyasi gelişmeler ve ardından gelen 2. Dünya Savaşı neticesinde eleştirilere tabi tutulması, uluslararası örgütlerle barışın sağlanamayacağını ortaya koymuştur. 2. Dünya Savaşı sonrasında teorik perspektifteki bu boşluğu, 1970’lere kadar hâkim olacak realizm doldurmuştur. Realizmle birlikte uluslararası ilişkilerin ekseni, hukuk ve tarihe odaklanan idealizmin aksine siyaset bilimine kaymıştır. Amerikan siyaset bilimine hâkim pozitivist metodolojiyi benimseyen davranışsalcılık, alanın başat yaklaşımı haline gelmiştir. Realizmin pozitivist

28 Eren Düzgün, “Capitalism, Jacobanizm and International Relations”, Review of International Studies, basım öncesi çevrimiçi yayınlanan taslak, 17 Ekim 2017, doi: 10.1017/S0260210517000468, s.3.

29 Schmidt, The Political Discourse of Anarchy, s.22-23, 32, 37.

30 Eric Hobsbawm, Kısa 20. Yüzyıl, İstanbul, Sarmal Yayımcılık, s.90. 
metodolojiyi benimsemesi ve şimdiki zamanda gözlenen durumu gerçeklik kabul etmesi, tarihdışı analizler yapmasına neden olmuştur. Realizm, var olan anın gerçekliğini ezeli ve ebedi, yani değişmez olarak nitelendirmiştir. Örneğin egemenlik sahibi ve sınırları belli ülkesel ulus-devlet kavramını verili kabul eden realizm, bu siyasi yapılanmanın varoluş koşullarını sorgulamamıştır. Anarşik uluslararası sistem de verili kabul edilmiş, zaman ve mekân dışı bir kavram olarak ele alınmıştır. Ferguson ve Mansbach'ın da dediği gibi "tarihsel duyarlılıktan yoksun uluslararası ilişkiler teorisyenleri, basitçe geçmişin günümüze benzediğini varsaymıştır."

Dolayısıyla realizm devleti şeyleştirmiş, tarihsizleştirmiş, toplumsallığından uzak şekilde ele almıştır. Varolan devlet sistemi, yani 1648'de Vestfalya Antlaşması'yla kurulduğu varsayılan modern uluslararası sistem, hep varolmuş gibi ele alınmıştır. ${ }^{32}$ Bu bağlamda düşünüldüğünde realizmin eksik kalan yanı, çıkar temelli analiz yapmasına rağmen devletin neden belli çıkarlar peşinde koştuğunu sorgulamamasıdır. Devletler neyin çıkarına uygun olduğuna nasıl karar verir sorusu yanıtsız kalmıştır. Oysaki çıkar ve güç gibi kavramların tarihselleştirilerek devletlerin kimliği, siyasal kültürü ve toplumsal hafızası göz önünde bulundurularak analiz edilmesi gerekir. Kısacası realizmin sorunu, devlet ve sistem gibi kavramları verili kabul etmesi ve onları açıklamak yerine uluslararası ilişkileri onlarla açıklamasıdır. Kullandığı kavramların tarihselliğini ve hangi bağlamda ortaya çıktığını göz ardı etmesi, realizmin değişim sorununa odaklanmasını engellemiştir. Pozitivizmden kaynaklanan olana ve ana odaklanılması, tarihsel süreç içerisinde yaşanan değişim faktörünü dışlamasına neden olmuştur.

Zamanla realizmin değişimi açıklayamamasının nedeninin, değişimi tamamen reddetmesi olmadığına dair eleştiriler gündeme gelmiştir. Realizm, kusurlu ve kötü insan doğasından ötürü uluslararası politikaya çatışmanın hâkim olduğunu iddia etse de devletlerin bunu güç dengesi ve silahlanma politikasıyla sınırlandırabileceğine inanmıştır. Dolayısıyla realizme göre güçler dengesindeki değişim, savaşların sonuçlarına göre büyük devletler arasındaki ilişkilerin değişmesiyle sınırlıdır. Belli dönemlerde belli küresel aktörler ön plana çıkmıştır; ancak bunun dışında, ulus-devlet merkezli güçler dengesi sisteminin kendisinin değişebileceği göz önünde bulundurulmamıştır. ${ }^{33}$

Bu bağlamda realizm, Soğuk Savaş yıllarında yaşanan dönüm noktaları neticesinde dönüşüm yaşamış; 1962 Küba Krizi hakkında yapılan dış politika analizleri devletin her zaman akılcı davranamayabileceğini gösterdiğinde bencil insan doğasının ürünü olarak nitelendirilen kendi içinde bütünlükçü ve akılcı devlet kavramı yerini uluslararası sisteme vurgu yapan yapısal realizme bırakmıştır. ${ }^{34} \mathrm{Bu}$ nedenle realizmi tarihten tamamen yoksun bir disiplin olarak tanımlamak doğru değildir. Hobson ve Lawson’a göre "inşacılığın yükselişi ya da İngiliz Okulu gibi yaklaşımların yeniden ilgi çekmesi, uluslararası ilişkilerin tarihe dönüşünden ziyade disiplin içerisinde 19. yy’dan beri var olan eğilimlerin hızlanması ve derinleşmesi anlamına gelir.” Çünkü uluslararası ilişkiler çalışanları teorilerin geçerliliğini test etmek için her zaman tarihten faydalanmıştır. Dolayısıyla "belki de hepimiz aslında birer tarihçiyizdir.”35 Benzer şekilde Hobden da uluslararası ilişkilerde tarihe ‘dönüşten’ ziyade

31 Yale Fergoson ve Richard Mansbach, "Polities Past and Present”, Millemium, Cilt 37, No.2, 1989, s.378.

32 Vestfalyan düzeninin eleştirisi için Benno Teschke, The Myth of 1648, Verso Books, 2003; Benjamin de Carvalho et al., “The Big Bangs of IR”, Millennium, Cilt 39, No.3, 2011; Özlem Kaygusuz, "Egemenlik ve Vestfalyan Düzen”, Evren Balta (der.), Küresel Siyasete Giriş, İstanbul, İletişim Yayınları, 2014.

33 Mehmet Ali Tuğtan, “Güç, Anarşi, Realizm”, Evren Balta (der.), Küresel Siyasete Giriş, İstanbul, İletişimim Yayınları, 2014, s.125.

34 Evren Çelik Wiltse, “Liberalizm, İşbirliği, Kolektif Güvenlik ve Neoliberal Kurumsalcılık”, Balta (der.), Küresel Siyasete Giriş, s.138; Ali Balcı ve Tuncay Kardaş, "Realizm”, Kardaş ve Balcı (der.), Uluslararası İlişkilere Giriş, s.126.

35 John Hobson ve George Lawson, "What is History in International Relations?", Millennium, Cilt 37, No.2, 2008, s.419420; George Lawson, “The Eternal Divide?”, European Journal of International Relations, Cilt 18, No.2, 2010, s.204, 207. 
bir 'geri dönüş' yaşandığını belirtmiştir. ${ }^{36} \mathrm{Bu}$ iddialar, yukarıda belirtildiği gibi klasik realizmin hâkim olduğu tarihten uzak bir uluslararası ilişkiler anlayışının, aslında disiplinin varoluşsal ya da doğuştan gelen bir özelliği olmadığını, aksine belki de bu dönemin uluslararası ilişkiler tarihi içerisinde ana değil tali bir dönem olarak görülmesi gerektiği ihtimalini doğrular niteliktedir. Nitekim 1970’lerden itibaren realizme rakip olarak başka teoriler yükselişe geçmiştir. Bu hususta da yine tarihsel faktörlerin etkili olduğu söylenebilir. ABD'nin Vietnam'dan çekilmek zorunda kalması ve 1973 Yom Kippur Savaşı'nın ardından gelen petrol krizi, uluslararası politikada sadece askeri değil ekonomik gücün de etkili olabileceğini göstermiştir. ${ }^{37}$ Bunun üzerine liberal teorisyenler, realizmin askeri güvenlik devleti karşısında ticaret devleti gibi alternatifler öne sürmeye başlamıştır. ${ }^{38}$

Son olarak değinilmesi gereken bir husus, tarihsel analizin neden 1990'lardan itibaren popülerlik kazandığıdır. Haber, Kennedy ve Krasner, ABD’nin yalnızcılık politikasından vazgeçerek 20. yy'da dünya siyasetinin başat aktörlerinden birisi haline gelmesiyle diplomasi tarihine artan ilgi arasında bağlantı kurmuştur. Tam aksine Vietnam Savaşı yenilgisinden sonra diplomasi tarihi popülaritesini yitirmiş; yükselişe geçen yeni toplumsal hareketler, dikkatleri elitlerin ve yöneticilerin değil sıradan insanın tarihine çevirmiştir. ${ }^{39}$

Reus-Smit ise uluslararası ilişkilerin yüzünü tarihe dönüşünü açılkarken Soğuk Savaş’ın bitişine dikkati çekmiştir. İki kutuplu dönemin sonlanması, rasyonalizm ve pozitivizme dayalı evrensel akılcılık iddiası etrafında konumlanan ve bunu yaptığı ölçüde tarihsel araştırmayı dışlayan uluslarası ilişkiler anlayışının sorgulanmasına neden olmuştur. Egemen devletler arasındaki ilişkiye dair genellemelere ulaşma çabası, o zamana kadar sürekliliğe ve tekrara dayalı analizlerin tercih edilmesine neden olmuşken, Soğuk Savaş'ın bitişiyle değişim olgusu yeniden uluslararası ilişkileri ilgilendirir hale gelmiştir. Üstelik bu dönüşüm, realizmin başat konularından birisi olan savaşla değil, o güne kadar ihmal edilmiş sivil toplum, yeni bir demografik ve toplumsal yapının ortaya çıkışı ve güvenliğe dair düşünce kalıplarının değişmesiyle gerçekleşmiştir. Tüm bunlar, tarihsel araştırmayı merkezine alarak kimlik ve değerler gibi zaman ve mekâna göre değişen konuları vurgulayan inşacılığın ortaya çıkmasıyla sonuçlanmıştır. ${ }^{40}$ Fakat ilk inşacılar, realizmi eleştirseler de kendileri de ikincil kaynaklara, yani başkalarının tarihten çıkarttığı sonuçlara dayalı analizler yapmıştır. Ancak daha sonraki inşacılar, araştırmalarında bizzat tarihsel yöntemi kullanmayı tercih etmiş, birincil kaynaklarla çalışmış ve tarihsel araştırmada ikincil kaynaklara dayalı analiz yapmanın 'muğlâklığına' değinmişlerdir. ${ }^{41}$

Roberts ise tarih ve uluslararası ilişkiler arasındaki etkileşimin arttığı 1990 sonrası sürece son bir etmen olarak 11 Eylül saldırısını eklemiştir. Roberts, 11 Eylül sonrasında uluslararası ilişkiler çalışanlarının ilgisinin savaş ve barış gibi aynı zamanda diplomasi tarihinin ilgi alanı olan konulara kaymasının, iki disiplinin yeniden bir araya gelmesinde etkili olduğunu belirtmiştir. Hem tarihçilerin hem de uluslararası ilişkiler çalışanlarının çağdaş dünyayı anlamaya çalışması ve ilkinin aynı zamanda geçmiş ikincisinin ise geleceğe dair öngörüde bulunması, iki disiplinin birbirini tamamlaması

36 Stephen Hobden, "Tarihsel Sosyoloji”, Stephen Hobden ve John Hobson (der.), Uluslararası İlişkilerin Tarihsel Sosyolojisi, Sakarya Üniversitesi Yayınları, 2015, s.69, 89, 93.

37 Wiltse, s.138.

38 Richard Rosecrane, The Rise of the Trading State, Basic Books, 1986.

39 Stephen Haber et al., "Brothers Under Skin”, International Security, Cilt 22, No.1, 1997, s.38, 40.

40 Christian Reus-Smit, "Reading History Through Constructivist Eyes”, Millenium, Cilt 37, No.2, 2008, s.395-398.

41 Halvard Leira ve Benjamin de Carvalho, "Construction Time Again”, European Review of International Studies, Cilt 3, No.3, 2016, s.104, 106, 111. 
noktasında faydalı olacaktır. ${ }^{42}$ Benzer şekilde Colin ve Miriam Elman da tarih ve uluslararası ilişkiler çalışanlarının yeniden işbirliği yapmasında 11 Eylül'ün yarattığı kırılmaya değinmiştir. Soğuk Savaş’ın sonlanması gibi 11 Eylül de uluslararası ilişkiler çalışanlarını, temel aldıkları varsayımları sorgulamaya yönlendirmiştir. Batı merkezli uluslararası ilişkiler teorilerinin eleştirilmesi, hem alanın kendisinin hem de kullandığı Vestfalyan düzen gibi kavramsallaştırmaların tarihini yeniden düşünmeyi gerektirmiştir. ${ }^{43}$

Farklı uluslararası ilişkiler teorilerinin hangi tarihsel bağlamda ortaya çıktığı ve değiştiği bu şekilde ele alındıktan sonra aşağıdaki bölümde tarihsel bakış açısının uluslararası ilişkileri, birbirinden farklı kuramları aynı anda içerisinde barındıran çok boyutlu çalışmalara yöneltebileceğine dair görüşlere yer verilecektir. Kısacası tarihin uluslararası ilişkilere katkısı, kuramların sadece gelişimini değil kullanılabilirliklerini, yani pratik anlam kazanmalarını da sağlamasıdır.

\section{Kuramsal Çoğulculuk ve Tarih-Uluslararası ilişskiler Etkileşimi}

Levy tarih ve siyaset bilimi/uluslararası ilişkiler arasındaki farklılığın kendisinin de bir tarihi olduğunu, dolayısıyla her iki disiplinin zaman içerisinde yaşadığı dönüşümler çerçevesinde bazen birbirine yaklaştığını bazense uzaklaştığını belirtmiştir. Bu yüzden "iki disiplin arasında yapılacak karşılaştırma, zamanlamaya ve tarihsel bağlama dikkat etmelidir.” Örneğin 19. yüzyıldaki Rankeci-pozitivist 'bilimsel tarih' anlayışı, tarihçiden "bağımsız varolan geçmişin yeniden yaratılmasını amaçlamıştır." Yüzyılın sonundaysa 'gerçeğin belgelerde olduğu' fikri, yerini tarihin 'güncel endişeler ve kültürleri yansıttığı’ fikrine bırakmıştır. Hatta 1960’larda Annales Okulu’nun “analitik ve teori-merkezli oluşu, anlatı-teori ikiliğini tarihçiler ve siyaset bilimciler arasında ayrım yapmak için yararlı olabilecek bir ölçüt olmaktan çıkartmıştır." 1970’lerden itibaren tarihte anlatının önemi yine artmaya başlamış, siyaset biliminde de "nicel yöntemler ve oyun teorisinin kullanımı yaygınlaşmış, bu çerçevede iki disiplin birbirinden yeniden uzaklaşmıştır." Bu nedenle "tarihçilerin anlatı, sosyal bilimcilerin teori temelli açıklamalar yapma eğiliminde olduğu” iddiası yanlıştır. Teori, "genellenebilir insan davranışını açıklamak için kullanılabileceği gibi zaman ve mekân bağımlı olaylar serisini, hatta tek bir olayı yorumlamak için de" kullanılabilir. Dolayısıyla iki disiplin arasındaki fark, "teorik kavram ve modeller kullanıp kullanmadıkları değil, teoriyi nasıl kullandıklarıdır.” Levy’ye göre "siyaset bilimciler genel teoriler inşa edip onları test ederken tarihçiler tekil olayları yorumlamak için bir ya da birkaç teoriyi birden kullanır." 4

Dolayısıyla Levy, tarih disiplininin idiyografik olsa bile teoriden uzaklaşmadığını belirtmiştir. Teori konusunda tarihçinin siyaset bilimciden farkı, teorik bakış açısına sahip olup olmadığı değil, siyaset bilimcinin aksine çok nedenli, dolayısıyla birden fazla teoriye dayanan açıklamalar yapma çabasıdır. Dolayısıyla iki disiplin arasındaki fark yöntemseldir. ${ }^{45}$ Suganami de benzer şekilde tarihsel ve teorik açıklamalar arasında "uzlaştırılamaz bir farklılık olmadığını", ilkinde anlatının içerisinde pek çok kuramsal unsur barındırırken ikincisinde az sayıda değişken arasında nedensel ilişki kurulduğunu belirtmiştir. ${ }^{46}$

42 Geoffrey Roberts, "History, Theory and the Narrative Turn in International Relations”, Review of International Relations, Cilt 32, No.4, 2006, s.706, 714.

43 Colin Elman ve Miriam Elman, "The Role of History in International Relations”, Millennium, Cilt 37, No.2, 2008 , s.361.

44 Jack Levy, “Too Important to Leave to the Other”, International Security, Cilt 22, No.1, 1997, s.23, 25-28, 32.

45 Jack Levy, “Explaining Events and Developing Theories”, Coline Elman ve Miriam Elman (der.), Bridges and Boundaries, Cambridge, MIT Press, 2001, s.57, 59.

46 Hidemi Suganami, "Narrative Explanation and International Relations”, Millennium, Cilt 37, No.2, 2008, s.346-347. 
Tam da bu bağlamda tarihin, uluslararası ilişkiler disiplininin kuramsallaşmasında önemli bir rol oynayabileceği söylenebilir. Leira’ya göre uluslararası ilişkilerin siyaset bilimi ve tarihten bağımsızlaşması, beraberinde uzmanlaşma ve profesyonelleşmeyi getirmiş; bu ise ayrı bir disiplin olarak düşünülen tarihe ilginin zaman sıkıntısı gibi zorunlu veya tercihsel nedenlerle azalmasına neden olmuştur. Uluslararası ilişkiler kendi içerisinde derinleşip farklı bakış açıları geliştirdikçe diğer disiplinlerle etkileşimi azalmışıı: "Uİ disiplini büyüdükçe her birimiz disiplinin daha az bir kısmını bilme paradoksuyla karşı karşıyayız." Leira bu kopukluğu aşmanın ve çoğulcu bir uluslararası ilişkiler anlayışına ulaşmanın yolu olarak tarihle amatör ruhla ilgilenmeyi önerir. Edward Said'in profesyonelliği entelektüelliğe meydan okuyan bir engel olarak tanımlamasından yola çıkan Leira, uzmanlaşmanın büyük resmi görmemizi ve bağlantılar kurmamızı engellediğini hatırlatarak yaratıcılık için amatör ruhla merak etmeye devam etmek ve mesleki rutinden uzaklaşmak gerektiğini belirtmiştir. Diğer disiplinlerden yararlanmak, araştırmanın heyecanını saklı tutacaktır. Hatta Leira uluslararası ilişkilerde çoğulcu bakış açısının, tarihi ortak bir nokta olarak bütüncül şekilde ele alabileceğini belirtmiştir. Tarihin uluslararası ilişkiler çalışanları arasında tartışma yürütülebilecek ortak bir alan olduğunu ifade eden Leira, bunun nedeninin tarihin aslında her teorinin 'kısmi ve geçici' olduğunu bize göstermesi olduğunu belirtir. Tarih bize aynı meseleyle ilgili pek çok farklı teorik bakış açısı olabileceğini gösterir. ${ }^{47}$

$\mathrm{Bu}$ bağlamda bir sonraki bölümde tarihi bir yöntem olarak ele alan uluslararası ilişkiler kuramlarına değinilecektir. Çünkü önemli olan uluslararası ilişkilere sadece tarihi değil, 'tarih sorunsalını' geri getirmektir. Zira esas önemli olan tarihçinin geçmiş hakkında gerçeği ortaya çıkartması değil, geçmişe dair bazı bilgilerin neden diğerlerine kıyasla daha doğru kabul edildiğini araştırmaktır. ${ }^{48}$

\section{Uluslararası İlişkiler ve Tarihsel Yöntem: Metodolojik Analiz}

Uluslararası ilişkiler ve tarih arasındaki etkileşim, sadece pozitivist uluslararası ilişkiler teorilerinin bir tarihi olduğunu göstermekle kısıtlı kalmaz. Daha önemlisi, bazı uluslararası ilişkiler kuramlarının metodolojik olarak da tarihsel yöntemi kullanmasıdır. Bu bağlamda, bu bölümde, tarihsel sosyolojinin, tarihin olumsallığıyla sosyolojinin genellemelerini bir araya getirerek uluslararası ilişkilere yaptığı katkıya değinilecektir. Nitekim tarihsel sosyoloji, günlük ve kısa dönemli vakalara odaklanan sosyolojiden ve geçmişte yaşanan anlık, istisnai ve biricik olayları inceleyen klasik tarih anlayışından farklı olarak yapısal ve uzun erimli eğilimlere odaklanmıştır.

Hobson’a göre 'historofobik' olduğu düşünülen pek çok uluslararası ilişkiler çalışması, "tarihin şimdiki zamanı yeniden düşünmenin bir aracı olarak değil şimdiki zamanın kuramlarını teyit etmek için kazılacak bir maden olarak kullanıldığı enstrümentalist” bakış açısından uzaklaşmalıdır. Bu bağlamda uluslararası ilişkileri tarihdışı kılan iki temel unsur vardır. Bunlardan temposentrizm, "şimdiki zamanı geçmişe doğru tahmin eder. Böylece tarihsel çağlar ve devlet sistemleri arasındaki kesintili kırılmalar ve farklılıklar düzeltilerek gizlenir.” Kronofetişizm ise şimdiki zamanı yalnızca şimdiki zamanla açıklama hatasıdır ve bizi varolan düzeni doğallaştırma ve değişmez kabul etmeye zorlar. ${ }^{49}$ Oysaki zamanı geçmiş, bugün ve gelecek şeklinde birbirinden ayıran sınırlar yoktur. Bu şekilde kompartmantalize edilmiş bir tarih algısı, bizim kurguladığımız bir durumdur.

47 Halvard Leira, "International Relations Pluralism and History", International Studies Perspectives, No.16, 2015, s.24, $27-29$.

48 Nick Vaughan-Williams, "International Relations and the Problem of History”, Millennium, Cilt 34, No.1, 2005, s.118, 121.

49 John Hobson, “Tarihsel Sosyolojiyi Yeniden Uluslararası İlişkilere Dahil Etmek Neler Kazandırır?” Stephen Hobden ve John Hobson (der.), Uluslararası İlişkilerin Tarihsel Sosyolojisi, Sakarya Üniversitesi Yayınları, 2015, s.16-18, 22, 26-27. 
Bu bağlamda özellikle Annales Okulu'nun temsilcilerinden Braudel'in uzun vade (long duree) anlayışı önem kazanmıştır. Braudel, tarihin merkezine devleti alarak, sadece belge inceleme üzerine kurulu Rankeci bir yöntemle ve genellenemeyeceği argümanını temel alan idiyografik bakış açısıyla kurumsallaşmasına karşı çıkmıştır. Çünkü bu durumda tarih, genellemelere karşı olması nedeniyle sosyal bilimlerle kopuk bir ilişki kurmaktadır. Bu durumu 'sağırlar diyaloğu' olarak adlandırılan Braudel, bu tür bir 'olaylar tarihi' yerine 'bütünsel tarihi' önermiştir. Kısacası Braudel, gündelik hayatın mikro tarihi ile toplumun yapısal eğilimlerinin makro tarihini bütünleştirmiştir. Bunun için üç farklı mekânsal boyut geliştirmiş; en temelde çok yavaş değişen coğrafi ve fiziksel özellikler, ardından iktisadi-toplumsal yaşam, son olarak da siyasi olaylar yer almıştır. Braudel bu şemayı izlerken coğrafya, iktisat ve sosyoloji gibi disiplinlerden faydalanmış; ayrıca klasik tarihe göre düz bir çizgide doğrusal olarak ilerleyen zaman kavramını, 'toplumsal zamanların çokluğu' ile idame etmiştir. Bu farklı katmanlara coğrafi, toplumsal ve bireysel zaman; olaylar tarihi, konjonktürel tarih ve yapısal tarih ya da kısa, orta ve uzun vade gibi isimler takmıştır. Bu bağlamda Braudel'e göre tarihin sosyal bilimlere yaptığı en büyük katkı, uzun erimli yapıların dahi yavaş da olsa değiştiğini göstermesidir. ${ }^{50}$ Sonuç olarak Braudel'in öne sürdüğü bu çoklu zaman anlayışı, tarihi evrensel bir düz çizgide konumlandıran ilerlemeci ve Aydınlanmacı anlayıştan kurtulmasını; evrensellik iddiasından uzaklaştığı ölçüde de Batı’nın üstünlügü üzerine kurulu paradigmaları sorgulamasını sağlamıştır.

Tarihsel sosyolojinin uluslararası ilişkilere yansıması ise günümüz küresel siyasetini anlamak için sadece şimdiki zamana odaklanmanın yetersiz olduğunu göstermesindedir. Tarihsel sosyoloji, hem modern dünya siyasetinin tarihsel bağlam içerisine yerleştirilmedikçe anlaşılamayacağına dair inanç beslemekte hem de çeşitli disiplinlerden gelen bilgileri bir araya getirmektedir. Kısacası tarihsel sosyoloji, teorik bakış açısının disiplinlerarası yaklaşımları teşvik edeceği fikrini doğrular niteliktedir. Hobson ve Lawson'un da dediği gibi "tarihsel sosyolojinin temel faydası, hem tarihsel açıdan zengin hem de teorik açıdan verimli araştırma yapma kapasitesidir." ${ }^{51}$ Tarihsel sosyoloji olayları detaylandırarak aktarmak yerine uzun erimli yaklaşımı sayesinde tarihsel dönemleri kavramsal boyutta ele almıştır. Örneğin Skocpol, toplumsal yaşamı iç sınıfsal yapı, uluslararası sistem ve bu ikisi arasında yer alan özerk bir alan olarak devlet bağlamında üç farklı mekânsal boyut çerçevesinde incelemiştir. ${ }^{52}$ Böylelikle tarihsel sosyoloji, adının da ima ettiği gibi, sadece tarih ve sosyolojiyi değil aynı zamanda siyaset bilimi ve uluslararası ilişkileri de ilgilendirir bir nitelik kazanmıştır.

Bununla da bağlantılı olarak, tarihin uluslararası ilişkilerin kuramsallaşmasına yapabileceği bir diğer katkı, iki disiplinin sosyal bilimlere dair teorik tartışmaların ana eksenlerinden birisi olan zamanmekân boyutunda işbirliği yapabilecek olmasıdır. ${ }^{53}$ Uzun erimli süreç ve dönüşümleri inceleyen araştırmalar, karşılaştırmalı çalışmalara olanak verdiği ölçüde farklı mekânlarda gerçekleşen farklı tarihleri inceleme konusu yapmıştır. Örneğin tarihsel sosyoloji uluslararası ilişkilerin hem tarihsel hem de sosyolojik olarak incelenmesi gerektiğini savunduğu için günümüze dair küresel sorunları zamanmekân bağlamında değerlendirmiştir. Çünkü bir yandan 'devletin tarihselleştirilmesini’ diğer yandan da 'uluslararası bağlam içerisindeki tarihin yerini' sorunsallaştırmıştır. ${ }^{54} \mathrm{Bu}$ sayede tarihsel sosyoloji,

50 Emrah Gülsunar, “Fernand Braudel: Yapısal Tarih”, Faruk Yalvaç (der.), Tarihsel Sosyoloji ve Uluslararası İlişkiler, Ankara, Nika Yayınevi, 2018, s.37-48.

51 Hobson ve Lawson, “What is History in International Relations?”, s.417.

52 Theda Skocpol, Devletler ve Toplumsal Devrimler, İstanbul, İmge Kitabevi, 2004, s.23-98.

53 Davenport, "The International and the Limits of History", s.250.

54 Fred Halliday, "Bir Uluslararası Sosyolojiye Doğru”, Stephen Hobden ve John Hobson (der.), Uluslararası İlişkilerin Tarihsel Sosyolojisi, Sakarya Üniversitesi Yayınları, 2015, s.347. 
uluslararası ilişkilerdeki iç-dış politika ayrımını sorgulayarak sadece uzun erimli yapısal unsurların değil aynı zamanda toplumsal faktörlerin de küresel siyasete etkisini incelemiştir. ${ }^{55}$ 'Dünya sosyolojisi' olarak da adlandırılabilecek olan tarihsel sosyoloji, "ulusal ve uluslararası alanların birbirinin içine geçmiş olduğunu ve karşılıklı olarak oluşturulduğunu” ortaya koymuştur. ${ }^{56}$

Bu bağlamda tarihsel sosyoloji içerisinde son yıllarda etkisi artan 'eşitsiz birleşik gelişme' (EBG - uneven and combined development) kavramına ayrıca değinmek gerekir. Rosenberg, EBG’yi şu şekilde tanımlamıştır: Dünya eşit olmayan, birbirinden çok farklı toplumlardan oluşur. Bu toplumlar sadece eşzamanlı olarak birarada varolmaz, aynı zamanda birbirleriyle etkileşime girer. Bu da onların varolma koşullarını birleşik (combined) hale getirmiştir. Bu etkileşim, toplumsal değişim ve tarihsel gelişmenin motorudur. $^{57}$

EBG’nintemelinde,Marksistlerin 19.yysonuve20.yybaşındakendiaralarındayaptıklarıtartışmalar yatar. Buna göre Kautsky, kapitalizmin nihayetinde tekelleşmiş bir sermaye oluşumuna evrileceğini iddia ederken, Rusya’nın Marks'ın öngördüğü biçimde doğrusal bir çizgide kapitalistleşmediğini analiz eden Troçki ise kapitalizmin eşitsizlikler üzerine kurulu dinamik yapısı nedeniyle devletler arasındaki güçler dengesinin sürekli değiştiğini gözlemlemiştir. Dolayısıyla uluslararası kavramının kendisi ve onunla bağlantılı olarak jeopolitik mücadele sürekli yeniden üretilmektedir. Rosenberg bu analizi temel alarak EBG'nin birbirinden farklı sanayileşme modelleri ve devlet yapıları geliştirdiği sonucuna varmıştır. $\mathrm{Bu}$ devletler, birbirleriyle jeopolitik mücadeleye girmiş, böylelikle uluslararası sistem ortaya çıkmıştır. Dolayısıyla Rosenberg, klasik Marksizm’in sermayenin tekelleşmesi öngörüsünü reddetmiştir. Ona göre sanayi devletleriyle diğerleri arasındaki ilişkide azgelişmiş ülkeler edilgen pozisyonda değildir. Sanayileştikçe eski düzene ait yapı ve normlar ortadan kaybolmamakta, dönüşerek eski ve yeninin içiçe geçtiği amalgam formlar ortaya çıkmaktadır. Örneğin geç sanayileşen devletler hızlı sanayileşmeyi gerçekleştirebilmek için devlete ekonomide ayrı bir yer atfetmiş; böylece liberal ekonomik sistem Almanya'da gözlemlendiği gibi ironik şekilde otoriter devlet yapıları ortaya çıkartmıştır. Bu da klasik Marksist kuramın öngördüğünün aksine homojen bir devlet sisteminin ortaya çıkmasını engellemiştir. Kısacası tam da EBG yüzünden çoklu bir devlet sistemi ve uluslararası kavramının kendisi vardır. ${ }^{58}$

Böylelikle ilk olarak Troçki tarafından kullanılan EBG'nin tarihsel sosyolojiye mekânsal bir bakış açısı kattığı söylenebilir. Troçki bu kavramla, Rusya gibi sanayileşme yolunda geç kalmış devletlerin bunu bir avantaja çevirip gelişmiş ülkelerin kazanımlarını benimseyerek klasik Marksist teorinin öngördüğ̈ aşamalardan geçmek yerine 'sürekli' bir devrim yaşayacağını ileri sürmüştür. EBG ortaya çıktığı bu ilk haliyle her ne kadar Avrupa merkezci bir nitelik taşısa da sonrasında bu kavramdan yola çıarak uluslararası ilişkilerin tarihi bir analizini yapan Rosenberg ve Hobson gibi teorisyenler bu engelin üstesinden gelmiştir. İlk olarak EBG’yi kapitalizmin ortaya çıkışıla başlatan teorisyenlerin aksine, dünya tarihinin geneline yayarak Avrupa kıtasının gelişiminin ardında yatan Doğu'yu 'taklit etme’ faktörüne değinilmiştir. İkinci olarak ise uluslararası ilişkilerin yapitaşlarından birisi olan devletle özdeşleştirilen düzen/egemenlik ile sistemle özdeşleştirilen anarşi kavramlarının içerisinde

55 Stephen Hobden, International Relations and Historical Sociology, London \& New York, Routledge, 1998, s.8, 177.

56 Hobson, “Tarihsel Sosyolojiyi Yeniden Uluslararası İlişkilere Dahil Etmek Neler Kazandırır?” s.28, 32.

57 Justin Rosenberg, “Uneven and Combined Development”, Alexander Anievas ve Kamran Matin (der.), Historical Sociology and World History, London \& New York, Rowman \& Littlefield, 2016, s.17.

58 Beyhan Erkurt, "Justin Rosenberg: Sivil Toplumun İmparatorluğu”, Yalvaç (der.), Tarihsel Sosyoloji ve Uluslararası İlişkiler, s.293-294; Çağlar Oyman, "Devletler Sistemi ve Kapitalizm”, Yalvaç (der.), Tarihsel Materyalizm ve Uluslararası İlişkiler, s.129, 137-138, 143-146, 153; Çağdaş Özeniş, “Eşitsiz ve Birleşik Gelişme Kuramı ve 'Uluslararası'nın Kuramsallaştırılması", Yalvaç (der.), Tarihsel Materyalizm ve Uluslararası İlişkiler, s.302-303. 
barındırdığı iç-dış ayrımı sorgulanmış, sosyolojiye uluslararası bir nitelik, uluslararası ilişkilere de sosyolojik bir nitelik kazandırılmıştır. ${ }^{59}$

Hatta Rosenberg bir adım daha öteye giderek uluslararası kavramının kendisini bu bağlamda tanımlamıştır. Ona göre uluslararası, "insanın varoluşunun toplumsal ve tarihsel eşitsizliğinden" kaynaklanır. Çünkü "herhangi bir zamandaki sosyokültürel çeşitliliğin somut dokusu olumsalken (contingent) bu çeşitliliğin gerçekliği olumsal değildir." Bu nedenle eşitsizlik, 'evrensel bir kanun'dur. Yani amaçlanan, genellenebilir tarihi modeller bulmak değil, farklılığın altını çizmektir. ${ }^{60} \mathrm{Bu}$ bağlamda tarihsel sosyoloji, evrensel süreçler yerine mekânsal farklılıklara değinmiştir. Bunu yaparken de eşzamanlı gerçekleşen olaylar arasındaki bağlantı ve etkileşimleri ortaya koymuştur. Kısacası önemli olan sadece farklılığın varlığını göstermek değil, farklı mekânsal durumların aynı zaman dilimi içerisinde birbirini nasıl etkilediğini sergilemektir.

Rosenberg'e göre bu çeşitlilik, eşitsizlik ve etkileşim, uluslararası ilişkilerin vazgeçilmez kavramlarından birisi olan anarşinin de temelinde yatar. Bu yüzden "uluslararası aslında her yerdedir" ve "iç-dış arasındaki yanlış (ontolojik) ayrım" ortadan kalkar. Uluslararası, EBG’nin "en yüksek seviyesidir”. EBG ise uluslararasının "sosyolojik tanımıdır." Kis Kacası, "uluslararası, insanlık tarihinin temel özelliklerinden birinin, yani toplumsal varoluşun başlangıçtan beri çoğulcu ve interaktif nitelik taşımasının bugün şekil bulmuş halidir." ${ }^{2}$ Bu nedenle EBG, bize "uluslararasının önemini tamamen kavramak için uluslararası ilişkiler disiplininin ötesine geçmemiz gerektiğini” ${ }^{63}$ göstermiştir. Kısacası uluslararasının önemini anlamak için uluslararası ilişkileri disiplinlerarası bağlamda ele almak gerekir.

Benzer bir durum sosyoloji için de geçerlidir. Sosyoloji, toplumlar arasında gerçekleşen etkileşimleri göz önünde bulundurmadı̆̆ için en fazla üzerinde durduğu kavramlardan birisi olan moderniteyi Avrupa tarihiyle özdeşleştirmiş ve Avrupa-merkezci bir bakış açısı geliştirmiştir. Bu durum, sosyoloji ile 'uluslararası' kavramı arasında kopukluk yaratmış ve farklı toplumsal değişim ve gelişim hikâyeleri sosyologlar tarafindan gözardı edilmiştir. Oysaki tam da bu noktada sosyoloji, tarih ve uluslararası ilişkiler disiplinleri arasında ortak bir payda bulunabilir. ${ }^{64}$ Örneğin bu bağlamda

59 Faruk Yalvaç, “Tarihsel Sosyoloji ve Uluslararası İlişkiler”, Uluslararası İlişkiler, Cilt 10, No.38, 2013, s.17-19. Düzgün, EBG’yi kapitalizmle başlatıp başlatmama tartışmasının ötesine geçerek modern dönemde dahi kapitalizm dışında alternatifler olduğuna dikkat çekmiş; Jakobanizm kavramına başvurarak Osmanlı İmparatorluğu'nun modernleşme hikâyesini bu iki kavram dâhilinde analiz etmiştir. Düzgün, "Capitalism, Jacobanizm and International Relations”, s.4.

60 Justin Rosenberg, "Why Is There No International Historical Sociology?” European Journal of International Relations, Cilt 12, No.3, 2006, s.313, 317-319. Bu bakış açısı dünya tarihçileri tarafından da paylaşılır. Örneğin Kara Ölüm’ün neden olduğu ekonomik kriz sonucunda Çin'de iktidara gelen Mingler, denizlerden çekilme kararı almış; dolayısıyla Portekizliler Hint Okyanusu'na ulaştığında onları durdurabilecek güçlü bir Çin donanmasıyla karşılaşmamıştır. Bu bakış açısıyla Abu Lughod, dünya tarihinin dönüm noktalarından biri olan ve tarihyazımının halen en etkin bakış açılarından birisini teşkil eden Batı’nın yükselişinin, dünyanın doğusunda yaşanan gelişmelerle bağlantısını kurmuştur. Bkz. Janet Abu-Lughod, “The World System in the Thirteenth Century”, Michael Adas (der.), Islamic and European Expansion, Philadelphia, Temple University Press, 1993.

61 Rosenberg, “Why Is There No International Historical Sociology?”, s.322-323, 327-328.

62 Rosenberg, "Uneven and Combined Development", s.27.

63 Ibid., s.30.

64 Alexander Anievas ve Kamran Matin, "Historical Sociology, World History and the Problematic of the International", Alexander Anievas ve Kamran Matin (der.), Historical Sociology and World History, London \& New York, Rowman \& Littlefield, 2016, s.1, 3. Modernitenin Avrupa-merkezci yorumunu eleştiren tarihyazımı içerisindeki benzer bir bakış açısı için 'eşzamanlı modernite' kavramına değinilebilir. Buna göre modernite, dünyanın çeşitli coğrafyalarında birbirinden çok farklı toplumsal, ekonomik, siyasi ve kültürel koşullarda yaşayan insanlar tarafindan paylaşılan ve içerisinde eşitsiz iktidar ilişkileri barındıran zamansal bir durumdur. Bkz. Harry Harootunian, Overcome by Modernity, Princeton University Press, 2000; Harry Harootunian, History's Disquiet, New York, Columbia University Press, 2002. 
sosyolojiden beslenen uluslararası ilişkiler çalışanları, modernite kavramı üzerine yeniden düşünmüşve moderniteye geçiş hakkında yazılanlar sayesinde modern uluslararası sistemi belirleyen özelliklerden olan ülkesellik ve egemenliğin tarihselliğini fark etmiştir. ${ }^{65}$

Ayrıca EBG’ye başvurarak sadece farklı disiplinler arasında bir diyalog kurmak değil, uluslararası ilişkileri etkileyen özne-yapı ayrışması gibi ikiliklerin de üstesinden gelmek mümkündür. Çünkü bu kavram, "eşitsiz iktidar ilişkilerinin oluşturduğu karmaşık yapıda farklı şekilde konumlanmış 'yeni' toplumsal düzenler yaratmak veya varolanları tanzim etmek için erişilebilir kaynakları ödünç alan veya onlara uyum sağlayan canlı özneleri içerisinde barındırır." ${ }^{\prime 6}$ Yani gerek özne gerek yapı gerekse bunlar arasındaki ilişki ve tüm bunların bir araya gelmesinden ortaya çıkan etkileşim, EBG’nin ilgi alanı içerisindedir.

Kısacası tarihin uluslararası ilişkiler için önemi, sadece günümüz dış politikasının tarihsel olarak uzun veya kısa vadede nasıl belirlendiğini ortaya koyması değildir. Bu ancak tarihi, düz bir çizgide ilerleyen olaylar silsilesinin ifşası olarak ele alan geleneksel-anlatısal bakış açısının yansıması olabilir. Önemli olan sadece uluslararası ilişkilerin tarihine odaklanmak değil, aynı zamanda günümüz uluslararası ilişkiler literatüründe kullanılan kavramsal araçların tarihselleştirilmesi ve hangi dönemde ne amaçla ön plana çıkartıldıklarının sorgulanmasıdır. Bu yapıldığı takdirde uluslararası ilişkilerin en önemli yöntemsel tartışma konularından birisi olan analiz düzeyleri ve yapı-yapan sorunu da netlik kazanabilir. Tarihsel bakış açısı, uluslararası ilişkilere disiplinlerarası bir nitelik kattığı ölçüde farklı analiz düzeyleri veya yapı-özne arasında bir ayrım yapmak yerine bütünlükçü bir perspektif sunabilir.

\section{Analiz Düzeyleri ve Disiplinlerarasılık:}

Özdemir, uluslararası ilişkileri “interdisipliner bir disiplin” olarak tanımlamıştır. Bunun nedeni, ilgi alanı gereği zamana, mekâna ve kültüre göre değişen özelliklere sahip ülke ve devletlerarası ilişkileri incelemesidir. Uluslararası politika ve uluslararası ilişkiler arasındaki ayrıma bakıldığında, uluslararası politika, devletler arasındaki siyasi ilişkileri inceler. Uluslararası ilişkilerse sadece diplomasiyle değil, aynı zamanda devletdışı aktörler, yani toplum, çokuluslu şirketler, uluslararası örgütler gibi aktörler arasındaki ilişkiyi gündemine almıştır. Diğer bir deyişle uluslararası politika devletler arasındaki diplomatik ilişkilerle ilgilenirken uluslararası ilişkiler sadece devletler değil, ülkeler arasındaki ilişkiyi de incelemiştir. Bunun içerisine ekonomik, ticari, kültürel etkileşimler de girer. Dolayısıyla inceleme alanları arasında uluslararası ekonomi, uluslararası ticaret ve uluslararası hukuk gibi konular yer almıştır. Bu yüzden uluslararası ilişkiler çalışanları sosyoloji, psikoloji, antropoloji, hukuk, tarih ve iktisat gibi diğer sosyal bilim dallarından yararlanmak zorundadır. ${ }^{67}$

Uluslararası ilişkilerin en az $\ddot{u} c_{c}^{68}$ analiz düzeyine sahip olması da onu disiplinlerarası kılmıştır. Örneğin bireyi analiz düzeyi olarak ele alan bir uluslararası ilişkiler çalışanı psikolojiden, devleti analiz

65 Düzgün, "Capitalism, Jacobanizm and International Relations", s.3.

66 Anievas ve Matin, s.7.

67 Haluk Özdemir, "Uluslararası İlişkilerin Disiplinlerarası Niteliği”, Haydar Çakmak (der.), Uluslararası İlişkiler, İstanbul, Doğu Kitabevi, 2014, s.69-75.

68 Uluslararası ilişkilerde birey, devlet ve sistemden oluşan üç analiz düzeyinin ötesine geçen teoriler de vardır. Örneğin bölge bir altsistem olarak tanımlanmaya başlanmıştır: Bkz. Gökçen Yavaş, “Bölge, Bölgeselleşme, Güvenlik”, Hasret Çomak ve Caner Sancaktar (der.), Uluslararası İlişkilerde Teorik Tartışmalar, İstanbul, Beta Yayınları, 2013. Ayrıca bürokrasi ve lobi grupları da analiz düzeyi olarak ele alınabilir: Bkz Chris Brown ve Kirsten Ainley, Uluslararası İlişkileri Anlamak, İstanbul, Sümer Kitapevi, 2013, s.82. Son olarak kompleksite kuramı çerçevesinde süreç ve/veya etkileşim kavramlarının da birer analiz düzeyi olarak düşünülebileceği ortaya konulmuştur: Bkz Hasan Yükselen, "Kompleksite Kuramı ve Diyalektik”, Yalvaç (der.), Tarihsel Materyalizm ve Uluslararası İlişkiler, s.347, 365. 
düzeyi olarak alan bir araştırmacı siyaset bilimi, sosyoloji, tarih ve hukuk gibi dallardan, sistemi analiz düzeyi olarak ele alan biriyse iktisattan faydalanmak zorundadır. ${ }^{69}$ Bu bağlamda tarih ve uluslararası ilişkiler arasındaki etkileşim ve işbirliği, alanı uzun zamandır ilgilendiren analiz düzeyleri ve yapıyapan tartışmasına son bir nokta koyma fırsatı sunabilir.

Mabee’nin da belittiği gibi “mikro-makro ayrımı, varoluşsal bir adanmışlık olmaktan çok aslında sorun-odaklı analitik bir ayrımdır." Önemli olan ikisi arasında tercihte bulunmak yerine her araştırma sorusuna uygun analiz düzeyini seçmektir. Çünkü "mikro-makro yaklaşımlar birbiriyle çatışan değil, birbirini tamamlayan unsurlar olarak görülmelidir.” Buna rağmen uluslararası ilişkilerde genel olarak devlet aktör, uluslararası sistemse yapıyla özdeşleştirilmiştir. Dolayısıyla mikro-makro ayrımı aslında araştırılan konuya bağlı olarak belirlenen bir araştırma stratejisi iken "analitik düzeyler meselesini özneyapı sorunuyla karıştırmak, her düzeyde yapı ve öznenin varolduğunu gözardı etmiştir.” Bu nedenle, "uluslararası ilişkilerin yüzünü tarihe dönmesi, toplumu bir bütün olarak görmeye adanmışlıkla tamamlanmalı ve analiz düzeylerinin şeyleştirilmesiyle uğraşılmamalıdır."70

Gilbert da geçmişten çıkartılacak derslerin günümüzdeki hangi siyasi soruna uyarlanabileceği sorusuna net bir yanıt verilememesi nedeniyle, bazı uluslararası ilişkiler çalışanlarının tarihe sırtını dönerek teori oluşturma arayışına girdiğini belirtmiştir. Gilbert aksine, yapı-yapan ilişkisi ve nesnellik sorunları bağlamında, tarihin neden uluslararası ilişkiler çalışanları için faydalı olabileceğini analiz etmiştir. Siyasi olayların içerisinde geçtiği koşulları dikkate almak, "bir ülkenin liderlerinin asla tam anlamıyla özgür olmadığını” gösterecek ve dış politika kararlarını “yargılarken daha dikkatli olmamızı” sağlayacaktır. Uluslararası ilişkiler çalışanları, süregelen "özgür irade ve determinizm tartışmasına nihai çözüm bulmakla yükümlü değildir.” Ancak tarih bize, bireysel karar alıcıların önlerindeki seçenekleri kısıtlayan yapısal unsurlar olduğunu gösterecek ve günümüz dış politika sorunlarının ardında yatan karmaşıklığı görmemizi sağlayacaktır. Bu sayede tarih, uluslararası ilişkiler çalışanlarına “mütevazı olmayı öğretebilir." Uluslararası ilişkiler çalışanları, bir liderin aldığı dış politika kararını onaylayabilir veya eleştirebilirler, "ancak bunu yaparken ... kendilerinin de yanlış olabileceğini” tarih bilgisi sayesinde unutmayacaklardır. Kısacası tarihi bilmek, nesnel bir dış politika analizi yapmamızı sağlayabilir çünkü objektif olmanın yolu, "aslında tam anlamıyla objektif olmanın asla mümkün olmadığını bilmekten geçer." ${ }^{71}$

Tam da bu noktada son bir not düşmek gerekir. Uluslararası ilişkilerin üçüncü büyük tartışması çerçevesinde alana dâhil olmaya başlayan tarihsel sosyolojik yaklaşımların çoğunun, alanın başat teorisi olan realizm ile ortak şekilde yapısalcı bakış açısını paylaştı̆̆ı söylenebilir. Zira Wallerstein'ın dünya sistemleri teorisi ile Waltz'un yapısalcı realizmi hemen hemen aynı dönemde ortaya çıkmıştır. Bu yaklaşımların her ikisi de yapıyı temel analiz düzeyi olarak almıştır. ${ }^{72}$ Ancak Marksizmin uluslararası ilişkiler disiplinine girişi bu şekilde yapısalcılık üzerinden gerçekleşirken tarihe en azından dünya sistemleri teorisi kadar önemli katkıda bulunan bir diğer tarihsel ekolün, 'alttan tarih'i (history feom

69 Aydınlı et al. uluslararası ilişkilerin disiplinlerarası niteliğine dikkat çeker: Aydınlı et al., Yöntem, Kuram, Komplo, s.3334, 49-53.

70 Bryan Mabee, "Levels and Agents, States and People”, International Politics, No.44, 2007, s.432-434, 446.

71 Arthur Gilbert, "International Relations and the Relevance of History”, International Studies Quarterly, Cilt 12, No.4, 1968, s.351, 355, 357. Yapı-özne sorunu için Alexander Wendt, "The Agent/Structure Problem in International Relations Theory”, International Organization, Cilt 41, No.3, 1987.

72 Evren Eken, "Anthony Giddens: Modern Devletler Sisteminin Ortaya Çıkışı, Egemenlik ve Şiddet”, Yalvaç (der.), Tarihsel Sosyoloji ve Uluslararası İlişkiler, s.168; Oyman, “Devletler Sistemi ve Kapitalizm”, s.125. 
below) savunan tarihçilerin uluslararası ilişkiler çalışanları tarafından aynı ilgiyi görmemesi ilginçtir. $\mathrm{Bu}$ nedenle tarih ve uluslararası ilişkiler disiplinleri arasındaki etkileşimin, ikincisinin daha fazla önem verdiği devlet ve sistem analiz düzeyleri çerçevesinde daha çok yapısalcı bakış açılarını ön plana çıkartan tarihsel sosyoloji çerçevesinde gerçekleştiği, bunun aksine bireysel aktörleri temel alan diğer tarihyazımı örneklerinin ise uluslararası ilişkiler çalışanları tarafından aynı ilgiyi görmediği söylenebilir. $\mathrm{Bu}$ hususta ender istisnalardan birisi, David Blaney ve Naeem Inayatullah tarafindan ortaya atılan ve genellikle postkolonyal teori çerçevesinde değerlendirilen 'aşağıdan uluslararası ilişkiler"73 kavramının ortaya atılması olmuştur.

\section{Sonuç}

$\mathrm{Bu}$ çalışmada tarih ve uluslararası ilişkiler disiplinleri arasındaki etkileşim, çeşitli eksenlerde ele alınmıştır. Öncelikle ontolojik olarak uluslararası ilişkilerin ayrı bir alan olarak varlığını tescil eden büyük tartışmalar içerisinde tarihin oynadığı role değinilmiştir. Tarihin bize uluslararası ilişkilerin belli siyasi-toplumsal koşullar çerçevesinde geliştiğini gösterdiği düşünüldügünde bu etkileşim, özellikle son tartışmalardan birisi olan pozitivizm ve postpozivitivizm arasındaki ayrışmanın aşılmasında etkili olabilir. Bu bağlamda pozitivizm ve postpozitivizm arasında tercihte bulunmak yerine, pragmatik bir bakış açısıyla, değişen koşullara göre siyaseten işe yarar bilginin ön plana çıkartılması gerektiğine dair görüşlere yer verilmiştir.

İkinci aşamada, tarih ve uluslarararası ilişkiler arasındaki etkileşim epistemolojik boyutta ele alınmış ve uluslararası ilişkiler kuramlarının tarihsel seyrine yer verilmiştir. Bu teorik çoğulculuktan, uluslararası ilişkilere tarihsel bakış açısıyla yaklaşılması sayesinde verimli şekilde faydalanılabileceğine değinilmiştir. Farklı teoriler arasında tercihte bulunmak yerine çok nedenli açılamalar yapan tarihsel analizler uluslararası ilişkilerde etkinliğini arttırdıkça farklı teorilere başvurma ihtimali de artacaktır. Son olarak metodolojik olarak tarihsel yöntemi kullanan tarihsel sosyoloji gibi uluslararası ilişkiler teorilerine yer verilmiş ve bu tür disiplinlerarası yaklaşımların uluslararası ilişkilerdeki bir başka tartışma konusu olan analiz düzeyleri ve yapı-yapan sorunlarının bütünlükçü perspektiften yaklaşılarak aşılmasına katkı sunabileceği belirtilmiştir.

Tarihsel bakış açısına sahip olduğu ölçüde evrensellik iddiasından uzaklaşan uluslararası ilişkiler teorileri, kullandıkları kavramları tarihselleştirdikçe farklı mekânsal düzeylerde vuku bulan hususlara da dikkat çekmeye başlamıştır. Bu bağlamda, disiplinin doğuş yıllarında alana içkin tartışmalardan birisi olan sömürgeci ve sömürge toplumlar arasındaki ilişki gibi farklı mekânsal düzeylerde gerçekleşen etkileşimler, tarihsel sosyoloji gibi yenilikçi yaklaşımlar tarafından yeniden gündeme getirilmiştir. $\mathrm{Bu}$ sayede alanın başat teorileri olan realizm gibi kuramlara içkin ve ulus-devlet kavramını evrensel bir norm olarak ele alan Avrupa-merkezci bakış açısının ötesine geçilerek uluslararası ilişkiler disiplinine gerçek anlamda bir uluslararası nitelik kazandırılmaya başlandığı söylenebilir.

73 David Blaney ve Naeem Inayatullah, "International Relations from Below," Christian Reus-Smit ve Duncan Snidal (der.), Oxford Handbook of International Relations, Oxford University Press, 2008. 